\title{
Attracting Foreign Direct Investment (FDI) In Nigeria through Effective Tax Policy Incentives
}

Raphael S. Etim ${ }^{*}$

Mfon S. Jeremiah ${ }^{2}$

Ofonime O. Jeremiah ${ }^{3}$

\section{${ }^{2,3}$ Department of Accounting, Faculty of Business Administration, University of Uyo. Uyo Alwa Ibom State, Nigeria. :Email:etimralph@yahoo.com \\ Licensed: \\ This work is licensed under a Creative Commons Attribution 4.0 License.}

Keywords:

Foreign direct investment

Tax policy incentives

Cost based tax policy incentives

Profit based tax policy incentives.

Accepted: 7 May 2019

Published: 20 May 2019

\begin{abstract}
Amidst the conflicting divides of diverse research findings on the effect of tax policy incentives on Foreign Direct Investment (FDI) in Nigeria, the focus of this study was to confirm the fact. Thus an empirical investigation covering a period of 19 years (1999-2017) was conducted to ascertain the effect of cost-based and profit based tax policy incentives on FDI in Nigeria. In line with the ex post facto research design adopted for the study, secondary data were sourced from CBN bulletins and World Bank Database. Multiple regression techniques was used in analysing the three models that were formulated. The findings revealed that although the cost based tax policy incentives had some relatively stronger effect on FDI (with $R^{2}$ of .230) compared to profit based tax policy incentives (with $R^{2}$ of .045), yet there was no significant relationship found between cost based tax policy incentives, profit based tax policy incentives and FDI in Nigeria. It was therefore recommended that non-tax incentive initiatives should be considered as a necessary complement to the tax policy incentives in order to attract and stabilize FDI in Nigeria.
\end{abstract}

Funding: This study received no specific financial support.

Competing Interests: The authors declare that they have no competing interests.

\section{Introduction}

\subsection{Background Issues}

The growing possibilities of globalization and the 'web' of economic interconnectedness among countries, opens up various foreign direct investment (FDI) prospects for investors beyond the borders of their home country. The pursuit of these prospects which often take the form of financial or real investments is increasingly embraced and encouraged in virtually every country of the world. This is because, in addition to other benefits it affords, investment (home or foreign) remains an important savings-complementing stimulant of economic growth and development (Jhingan, 2004). In view of this, countries of the world continue to evolve promising initiatives that are intended to encourage, retain and increase the inflows of FDI into their various countries. One of such dynamic initiatives is the introduction of incentives that are provided for foreign investors in the tax policy.

Basically, taxation is a way of raising revenue for the day to day running of government activities. It is also known that government activities involve generating revenue from tax or other sources and using the same to provide security, social amenities and infrastructural facilities (Akhor \& Ekundayo, 2016). The modalities on the assessment, collection and administration of tax revenues are specified in the tax policy. Moreover, beyond the popularly known objectives of revenue generation and wealth redistribution, governments adopt tax policy that provides incentives such as tax holidays and lower taxes for foreign investors in order to enhance its inflows of FDI (Ndagi, 2016). Different countries affect changes in their tax policies and incentive schemes as they deem necessary because of this belief that investment-friendly tax policy that affords competitive incentives to foreign investors is key in attracting FDI (Effiok, Tapang, \& Eton, 2013). 
In Nigeria, in a bid to gradually break the age-old jinx of the country's counter-productive overdependence on its mono-product (oil), tax policy initiatives that grant some tax incentives have been adopted with a view to enhancing FDI in several other sectors of interest. These tax policy incentives are either cost-based or profit based. The cost-based incentives are ultimately targeted at decreasing cost for the foreign investors while the profit based incentives assist in reducing the proportion of profits paid as tax (Institute for Fiscal Studies (IFS), 2018).

Okauru (2009) noted that the country's FDI drive has triggered some reform response by the government in key sectors such as the banking, power, transportation as well as in infrastructure tailored towards enhancing the conduciveness of the country's investment climate for foreign investors. In fact, Nigeria has been rated as the third host economy for FDI in Africa, behind Egypt and Ethiopia (United Nations Conference on Trade and Development (UNCTAD), 2018).

However, since the more recent tax incentive reforms in 1999, the country's net inflows of FDI as depicted by its percentage contribution to GDP has continued to fluctuate. These fluctuations and the consequent high unpredictability of FDI pose some limitation to economic planning. Statistics show a series of ups and downs in Nigeria's FDI. From a contribution of $1.693 \%$ in 1999, Nigeria's FDI contribution to GDP declined to $1.608 \%$ in 2001 . It rose to $1.965 \%$ in 2002 but two years after, in 2004, it again fell to $1.374 \%$. In 2005, a high FDI to GDP \% was recorded (2.829 \%) but as usual it fell to $2.056 \%$ the very next year, 2006 and struggled to rise to $2.189 \%$ in 2007 . Since the 1999 tax incentive reforms, the highest net inflow of FDI (\% of GDP) was $2.931 \%$ reported in 2009 but this raises questions about the tax incentive policy considering the fact that before the 1999 tax incentive reforms, the country had recorded net inflows as high as $4.848 \%$ and $5.791 \%$ in 1993 and 1994 respectively (World Bank, 2019).

More recently too, Trading Economics (2019) from a monetary (US dollars) based analysis, highlighted that FDI in Nigeria increased by 438.84 million US dollars in the third quarter of 2018 . For the period of 12 years spanning between 2007 and 2018, Nigeria's FDI averaged 1,261.83 US dollars. Within that period, the highest FDI value was 3084.90 US dollars recorded in the last quarter of 2012 while the lowest value recorded during the period (435.64 US dollars) was in the second quarter of 2018.

Also, UNCTAD (2018) reported a 21\% fall in Nigeria's FDI in 2017. These twist and twirls in FDI values raise doubts about the purported effectiveness of the tax incentive policy which is a major policy aimed at attracting FDI into the country.

Variants of studies have been conducted to investigate the impact of tax incentives on the pattern of FDI inflows in Nigeria. Interestingly, while the findings of most of those studies tend to be similar and that is that tax policy and incentives have a significantly positive effect on FDI (Amuka \& Ezeudeka, 2017; Effiok et al., 2013; Olaniyi, Ajayi, \& Oyedokun, 2018; Ugwu, 2018). Other studies found out the contrary (Peters \& Kiabel, 2015; Saidu, 2015; Sheedy, Zhang, \& Tam, 2017). This contrary view justifies further empirical investigation on the fact of the subject matter. Thus, this study seeks to confirm which of the two divides hold sway. This will be done from the perspective of cost-based and profit based tax policy incentives.

1.2. Objectives

The main objective of this paper is to ascertain the effect of tax policy incentives on FDI. The specific objectives are:

i. To ascertain the relationship between cost-based tax policy incentives and FDI in Nigeria.

ii. To find out the relationship between profit based tax policy incentives and FDI in Nigeria.

iii. To confirm the joint relationship between cost-based tax policy incentives, profit based tax policy incentives and FDI in Nigeria.

\subsection{Hypotheses}

The paper is guided by three tentative propositions:

$\mathrm{Ho}_{1}$ : There is no significant relationship between cost-based tax policy incentives and FDI in Nigeria.

$\mathrm{Ho}_{2}$ : There is no significant relationship between profit based tax policy incentives and FDI in Nigeria.

$\mathrm{Hog}_{3}$ : There is no significant joint relationship between cost-based tax policy incentives, profit based tax policy incentives and FDI in Nigeria.

\section{Literature Review \\ 2.1. Conceptual Review \\ 2.1.1. Foreign Direct Investment}

Investment refers to the acquisition of assets with a view to generating future income or appreciation in value (Chen, 2018). Investment is termed "foreign" if it is acquired in a foreign country, such investments may be direct or indirect. Direct investment is a kind of foreign investment which gives an investor a significant degree of influence on the foreign investee's management. Thus, Foreign Direct Investment (FDI) is defined as a cross border acquisition of financial or physical assets by foreign individuals or government with the investor having some controlling rights. These foreign direct investors could be individuals, corporate organizations or a nation (Odiase, 2006). 
Similarly, Financial Times Lexicon defines FDI as an investment which imbues controlling ownership in a business based in a country other than that of the investor (lexicon.ft.com). These definitions imply that FDI is defined by foreign controlling ownership which involves the external inflow of financial, human and real resources into a country from outside (Olaniyi et al., 2018). Ndagi (2016) clarifies that FDI is established when a foreign investor acquires at least $10 \%$ of the shareholding and voting rights of a foreign enterprise. This point brings clarity on the issue of controlling ownership. The acquisition of the minimum $10 \%$ shareholding proportion is deemed substantial and this gives the foreign investor a lasting management interest in the investee.

The importance of FDI which places it as a vital economic matter of concern is that through FDI, capital, technology and other managerial expertise, are sourced from foreign countries. It is true that FDI may be motivated by a number of reasons. Some of these reasons may be higher average rates of profits, markets and resources, development of new resources or tax incentives (Berkeley, 2019; Essays, 2018).

\subsubsection{Tax Policy and Incentives}

Tax policy is a document which specifies the monetary charges imposed by government on individuals, companies, transactions or properties for the purpose of revenue generation. In the tax policy, what, how much and, on whom to tax, is clearly spelt out (Olaniyi et al., 2018). Tax incentives are special tax policy arrangements provided for in the tax laws with a view to attracting, retaining or increasing investment in a particular sector. It is also intended to stimulate growth in specific areas and to assist companies or individuals carrying on identified activities (Okauru, 2009).

Tax incentives (also referred to as tax policy incentives) is also defined as any special tax provisions that are granted to qualified investments or investors and which affords such investors a favourable deviation from the general tax code (Ndajiwo, 2018). In other words, tax incentives grant some tax exceptions, deductions or exclusions to the beneficiaries (Berkeley, 2019).

Tax policy incentives have the capacity of generating desirable economic gains depending on how they are designed and implemented. As a result, incentives are reviewed regularly to ensure that they are serving their expected purpose (Okauru, 2009). Moreover, Easson and Zolt (2002) indicate that whereas tax incentives generally have the innate capacity of making investment more attractive, they cannot compensate for tax system deficiencies in such countries.

\subsubsection{Tax Policy Incentives for FDI in Nigeria}

It has been noted that for over a decade now, several tax incentive arrangement have been granted to multinational investors investing in Nigeria, with a view to attracting more FDI into the country.

Berkeley (2019) categorized these FDI tax incentives into five: pioneer status incentive, export incentives, rural location incentives, gas utilization incentives and, free trade zones incentives. Pioneer status incentive is provided for defined new qualifying investors in pioneer industries/products (FIRS, 2017). Export incentives are meant for export oriented industries who fall within the designated Export Processing Zone (EPZ) or Free Trade Zones (FTZ). Such incentives are meant to encourage investment in certain defined zones in the country. Rural location incentives are for businesses located in certain rural areas which are not close to available basic infrastructure. Gas utilization incentives are designed for companies that are involved in gas utilization activities (PwC, 2018).

However, Ndagi (2016), Ndajiwo (2018) and IFS (2018) specifically identified the various general forms of tax policy incentives which in application, take different forms based on sector, income type, business size, and business location of the investor. These incentives can also be specified as temporary or permanent and can also offer partial exemption or full-exemption (Ndajiwo, 2018) (FIRS, 2017). The incentives include: tax holidays, investment allowances, tax credit, accelerated depreciation allowance, reduced tax rate, loss carry forwards, zero or reduced tariff, tax credits and loss forwarding. From the cost-profit perspective, IFS (2018) stated that these tax incentives may be broadly divided into two categories: the cost-based and the profit based tax incentives.

\subsubsection{Cost-Based Tax Incentives}

Cost-based tax incentives are incentives which are meant to help investors by decreasing their cost of capital. However, it is noted that the benefits of cost-based incentives only accrue if capital investments are made. More so, cost-based incentives give rise to a higher additional investment gain for every unit of revenue forgone (IFS, 2018). Cost based incentives include investment allowances, tax credits, accelerated depreciation allowances and reduced tariffs. 
(i) Investment Allowances is one of several forms of corporate tax incentives (IFS, 2018). In order to reduce the effective price of acquiring new capital, the tax policy allows some deductions from the taxable income based on a given percentage of the qualifying new investment. Such deduction is referred to as an investment allowance (Ndagi, 2016). The magnitude of this incentive is sometimes defined by location or zone where the foreign investor is investing (FIRS, 2017). Company income tax Act (CITA) allows companies, including those in the solid minerals sector, an investment allowance of $10 \%$ on the actual expenditure incurred on plant and equipment (FIRS, 2017).

(ii) Accelerated Depreciation Allowances is a form of allowance which is usually granted for investments in plant and machinery (FIRS, 2017). It permits assets costs to be written off earlier than its useful economic life (Ndagi, 2016). With this incentive, taxpayer is given the privilege of claiming a higher depreciation deduction in the first or earlier years of the useful life of the asset (Kenton, 2018). The implication of this incentive is that while tax payments, in nominal terms, are unaffected, their net present value is reduced and the liquidity of the investing firms is improved (Klemm, 2010). The CITA provides an accelerated capital allowance of $95 \%$ on qualified capital expenditure on mining in the first year of use (FIRS, 2017).

(iii) Tax Credits is otherwise referred to as tax investment credit. It is given as a specified fraction of qualifying investment expenditures which may be fixed or incremental (Klemm, 2010). It may be given for value addition or for foreign hard currency earnings (Ndagi, 2016). Tax credits therefore allow investors to deduct investment costs directly from their tax liability (business dictionary.com).

(iv) Reduced Tariffs: Tariffs are taxes levied on imported goods and services (Smith, Pepelasis, Paya, \& McLure, 2019). Reduced tariff is the reduction of tariffs due on capital equipment and spare parts imported into the country for the purpose of undertaking a qualifying investment project. In some cases, where the entire tariff is completely eliminated, it is referred to as zero tariff incentive (Ndagi, 2016). Qualifying investing companies are given $0 \%$ import duty on equipment and machinery imported for mining operations, agriculture, aviation as well as power generation, distribution and supply (FIRS, 2017).

\section{(a) Profit-Based Tax Incentives}

Profit-based tax incentives are a set of incentives that is meant to assist investors by either reducing tax rates or granting them tax waivers on their profits. In terms of administration, it is deemed that profit based tax incentives are relatively easier to administer but challenging to monitor. These tax incentives include tax holidays, reduced tax rates or loss carry forwards (IFS, 2018).

(i) Tax holidays: this is a kind of incentive which exempts qualifying newly established firms from paying company income tax for a specified period. The tax holiday is a temporary incentive which eliminates tax on net revenues from investment projects only within the holiday period. It has been noted that tax holidays tend to benefit short-term projects with low upfront investment costs (IFS, 2018). FIRS (2017) provides a maximum of 5 years' tax holiday for new qualifying companies investing in Nigeria.

(ii) Reduced tax rates: This incentive sets a rate which is lower than the existing general tax rate, based on which the income of qualifying investors is taxed. According to Ndagi (2016), Nigeria has a fixed rate of $7.5 \%$ corporate tax rate for qualifying foreign investors from countries such as Britain, France, Belgium, Netherlands and others with whom it has tax treaty. Also qualifying companies in preferred sectors such as agriculture, manufacturing, solid minerals can enjoy a rate of $20 \%$ as against the general $30 \%$ company income tax rate (FIRS, 2017).

(iii) Loss carry forwards: For tax accounting purposes, this incentive allows specified proportion of losses incurred by new foreign investors to be carried forward usually for a minimum and maximum period of 3 and 5 years respectively. These carry forward constitute tax benefits because they will be offset against future taxable profit (Ndagi, 2016). For instance, FIRS (2017) prescribe that corporate losses incurred by investors during a tax relief period is deemed to be incurred on the first day following the expiration of the tax relief period and can be carried forward to offset profits after the tax exempt period.

\subsection{Theoretical Review}

The study is hinged on two theories: internalization theory and capital theory. Internalization theory is a branch of economics that facilitates the analysis of international business behaviour (Rugman \& Collinson, 2012). Although several scholars have contributed to the development of internalization theory over the years, the origin of the theory is traced to Ronald Cruse in his article in 1937. Internalization ensues when perceived benefits exceed costs (Hymer, 1976). In every normal business prospect, cost considerations are paramount because they determine the viability and continuity of any business firm. In foreign investment, tax regime in the investee country is one of the components of cost which has to attract or discouraging implications. Tax policy incentives are designed to mitigate the cost of investment for existing and would be investors. The cost of doing business abroad when made relatively minimal through the benefits afforded by tax incentives enhances perceived benefits for foreign investors.

Capital theory evolved through pre-classical and classical economic era. However, it is held that Carl Menger in his work in 1871 laid the foundation for what is referred to as a "comprehensive theory of capital" (Trivedi, 2009). Capital theory acknowledges the profit motive of every entrepreneur. Unfriendly tax policy or 
relatively higher tax costs diminish profit which overtime may probably affect the motivation for foreign investment. Amuka and Ezeudeka (2017) asserted that the recent aggressive use of tax incentives in attracting FDI is borne out of the notion that a favourable tax policy will have a positive effect on the flow of FDI into a country.

\subsection{Empirical Review of Studies}

In view of the importance of FDI, a number of related studies have been conducted on the tax policy incentives and FDI of various countries. However, since the focus of this study is on Nigeria, this empirical review is mainly limited to those studies concerning Nigeria.

Effiok et al. (2013) conducted a survey study on the impact of tax policy and incentives on FDI and economic growth. The study population was limited to the Export Processing Zones (EPZs) in Nigeria. Primary data, collected through interviews and the administration of a questionnaire to sampled respondents, were used for the study. Models were developed and the ordinary least square regression analysis technique was employed for the analysis of the data collected. The findings of the study revealed that tax rates which were a proxy for tax policy incentives, have a significant relationship with FDI and economic growth. Based on this, it was concluded that tax reform was necessary to make necessary changes in the tax incentives.

Peters and Kiabel (2015) examined the influence of tax incentives on FDI decision by foreign investors. Tax incentives were measured as annual tax revenue as a ratio of GDP. Secondary data covering the period of 32 years $(1980$ - 2011) were drawn from the CBN bulletin and World Bank Development Database for the study. It was found out that tax incentives had a negatively significant influence on FDI. Based on this, it was concluded that in the bid to attract more FDI to the country, other non -tax incentives should be considered.

Saidu (2015) examined the relationship between corporate taxation and FDI in Nigeria between 1970 and 2013. The CBN statistical bulletin and annual reports of NBS and World Bank provided the secondary data which was used for the study. The collected data were analysed with the aid of correlational and regression techniques. The findings of the analysis revealed that corporate taxation, which was measured by the corporate tax rates, had a negative significant relationship with FDI. It was therefore suggested that FDI can be attracted into the country if the rate of corporate taxation is reduced.

Amuka and Ezeudeka (2017) did an investigation to find out whether the introduction of tax incentive policy produces a significant change on the pattern of FDI flow in the non-oil sector of Nigeria. Companies income tax and investment allowance were the tax incentives considered. Secondary data was used for the study. Ordinary least square econometric analysis was employed for the data analysis. The findings of the study indicated that the introduction of tax incentives policy change the pattern of FDI flows in the sector. This suggests that tax incentives can be utilized as a veritable tool for attracting FDI in the non-oil sector.

Ugwu (2018) comparatively evaluated the contribution of tax incentives towards FDI inflow in three (3) African countries (Nigeria, Ghana and South Africa) in their pre and post IFRS adoption period. Secondary data was used for the study which covered a period between 1999 and 2015. It was found out that while a positive association exists between tax incentives and FDI, FDI did not have significant effect on the exports of those three countries. It was also found out that there was no significant difference in the effect of FDI on exports of this countries in their pre and post-IFRS adoption periods.

Olaniyi et al. (2018) investigated the impact of specific tax based policy incentives (company income tax incentives, petroleum profit tax incentives, value added tax incentives, customs and excise duties incentives) on inflows of FDI in Nigeria. The study covered a period of 23 years (1994-2016). Secondary data collected from CBN database was analysed using multiple regression and correlation techniques. The findings of the study showed that all the incentives studied, with the exception of company income tax incentives and petroleum profit tax incentives, had a significant impact on FDI. It was concluded that tax incentive policy plays a significant role in attracting FDI.

Tapang, Onodi, and Amaraihu (2018) conducted a study which was focused on the effect of tax incentives on FDI in the Nigerian petroleum industry. The tax incentive measures were investment tax allowance, nonproductive rent and capital allowance. Secondary data were collected and used for the study. The result of the regression analysis which was conducted showed that tax incentives have a significant effect on FDI in Nigeria. It was therefore recommended that effective implementation of this incentives is necessary in order to ensure maximal benefit by investors.

In examining the effect of tax incentive on FDI, each of these reviewed studies selected different identified forms of tax incentives, none of the studies considered tax incentives from the perspective of the cost based tax incentives and the profit based tax incentives. This approach will therefore be adopted in this study.

\section{Methodology}

The ex post facto research design was adopted for the study. The study was conducted using secondary data which was sourced from CBN bulletins and World Bank Data. The data covered a period spanning from 1999, the year of the tax incentive reforms, up to 2017. Multiple regression was employed in analysing the collected data in line with the study models.

$\mathrm{FDI}=\mathrm{f}($ cost based tax policy incentives (IVA, TXC) 
FDI $=\mathrm{f}($ profit based tax policy incentives $(\mathrm{TXH}, \mathrm{RTR})$

$\mathrm{FDI}=\mathrm{f}$ (cost based tax policy incentives, profit based tax incentives (IVA, TXC, TXH, RTR)

Thus, the regression models specified for the study are stated respectively as:

$\mathrm{FDI}=\mathrm{a}_{0}+\beta_{1} \mathrm{IVA}+\beta_{2} \mathrm{TXC}+e$

$\mathrm{FDI}=\mathrm{a}_{0}+\beta_{1} \mathrm{TXH}+\beta_{2} \mathrm{RTR}+e$

$\mathrm{FDI}=\mathrm{a}_{0}+\beta_{1}$ IVA $+\beta_{2} \mathrm{TXC}+\beta_{3} \mathrm{RTR}+\beta_{4} \mathrm{TXH}+$

Where:

FDI $=$ Foreign Direct Investment (measured using FDI net inflow (\% of GDP).

IVA $=$ Investment allowance

TXC $=$ Tax credits

TXH = Tax holiday

$\mathrm{RTR}=$ Reduced Tax rate (proxied by corporate tax rate)

$\mathrm{a}_{0}=$ Constant term

$\beta_{1}, \beta_{2} \ldots, \beta_{4}=$ Coefficient of the independent variables

$e=$ Error term

4. Results and Discussion of Findings

4.1. Cost based Tax Policy Incentives and FDI

Table-1. Regression Output on Relationship between TXC, IVA and FDI.

Model Summary ${ }^{\mathrm{b}}$

\begin{tabular}{c|c|c|c|c|c}
\hline Model & R & R Square & Adjusted R Square & Std. Error of the Estimate & Durbin- Watson \\
\hline 1 & $.479^{\mathrm{a}}$ & .230 & .134 & .59717 & 1.520 \\
\hline
\end{tabular}

\begin{tabular}{|c|c|c|c|c|c|c|}
\hline \multicolumn{2}{|c|}{ Model } & & (1) & & $\mathrm{T}$ & \\
\hline \multirow{3}{*}{1} & Regression & 1.703 & $\frac{11}{2}$ & .851 & 2.387 & $.124^{\mathrm{b}}$ \\
\hline & Residual & 5.706 & 16 & .357 & & \\
\hline & Total & 7.408 & 18 & & & \\
\hline
\end{tabular}

b. Predictors: (Constant), TXC, IVA

\begin{tabular}{c|c}
\hline Predictors & Standardized Coefficients (Beta) \\
\hline IVA & 2.029 \\
\hline TXC & -2.195 \\
\hline
\end{tabular}

The results show that cost based tax incentives (investment allowance (IVA) and tax credit (TXC)) correlate with FDI. The Durbin Watson value of 1.520 suggests that there are no significant autocorrelation problems. The $\mathrm{R}$ square value of 0.230 depicts that these cost-based tax incentives explain only $23 \%$ of the variance in FDI which is quite insignificant. On the ANOVA table, the insignificance of cost based incentives ability to explain the FDI is further confirmed by the p value of .124 which is greater than .05. On this basis, the null hypothesis is confirmed that there is no significant relationship between cost based tax incentives and FDI. Moreover, of the two variables, the standardized beta coefficients indicate that TXC makes a relatively slightly stronger contribution to explaining FDI. The TXC standardized beta coefficient of -2.195 indicates that a $1 \%$ increase in tax credits will change FDI by $2.195 \%$. On the other hand, IVA has a standardized beta coefficient of 2.029 which implies that a $1 \%$ increase in IVA helps to increase FDI by 2.029 .

4.2. Profit Based Tax Policy Incentives and FDI

Table-2. Regression Output on Relationship between TXH, RTR and FDI.

Model Summary

\begin{tabular}{l|c|c|c|c|c}
\hline Model & $\mathbf{R}$ & R Square & Adjusted R Square & Std. Error of the Estimate & Durbin-Watson \\
\hline 1 & $.211^{\mathrm{a}}$ & .045 & -.075 & .66511 & .793 \\
\hline $\begin{array}{l}\text { Note: a. Predictors: (Constant), TXH, RTR } \\
\text { b. Dependent Variable: FDI }\end{array}$
\end{tabular}




\begin{tabular}{|c|c|c|c|c|c|c|}
\hline \multicolumn{7}{|c|}{ ANOVA $^{\mathrm{a}}$} \\
\hline & Todel & Sum of Squares & df & Mean Square & $\mathbf{F}$ & Sig. \\
\hline \multirow{3}{*}{1} & Regression & .330 & 2 & .165 & .373 & $.694^{\mathrm{b}}$ \\
\hline & Residual & 7.078 & 16 & .442 & & \\
\hline & Total & 7.408 & 18 & & & \\
\hline
\end{tabular}

b. Predictors: (Constant), TXH, RTR

\begin{tabular}{c|c}
\hline Predictors & Standardized Coefficients (Beta) \\
\hline RTR & -.397 \\
\hline TXH & .213 \\
\hline Source: Researchers Computation using SPSS v 20.
\end{tabular}

The result shows that both RTR and TXH correlate with FDI. With a tolerance value of .122 which is above the threshold of .10; multicollinearity concerns are minimized. The $\mathrm{R}$ square value is quite infinitesimal (.045). This $\mathrm{R}$ square value indicates that only about $4.5 \%$ of the variance in the FDI is explained by these two profit based tax incentives. Also, the p value (.694) on the ANOVA table is greater than the .05. These confirm the null hypothesis that there is no significant relationship between profit based tax incentives and FDI. However, the standardized beta coefficients indicate that RTR makes a relatively stronger unique contribution (-.397) to explaining FDI. TXH has a standardized beta coefficient of .213 denoting that for every 1 year of tax holiday incentive granted, FDI increases by $21.3 \%$; whereas a $1 \%$ decrease in tax rate (RTR) will increase FDI by $39.7 \%$. These finding corroborate that of previous studies by Saidu (2015) which found out that negative significant relationship between corporate tax rate and FDI in Nigeria. It also agrees with Klemm and Parys (2009) that lower corporate income tax rates and longer tax holidays are effective in attracting FDI.

\subsection{Cost Based Tax Incentives, Profit Based Incentives and FDI}

Table-3. Regression Output on Relationship between TXH, IVA, TXC, RTR and FDI.

Model Summary ${ }^{\mathrm{b}}$

\begin{tabular}{l|c|c|c|c|c}
\hline Model & $\mathbf{R}$ & R Square & Adjusted R Square & Std. Error of the Estimate & Durbin-Watson \\
\hline 1 & $.528^{\text {a }}$ & .279 & .073 & .61778 & 1.518 \\
\hline
\end{tabular}

ANOVA $^{\mathrm{a}}$

\begin{tabular}{|c|c|c|c|c|c|c|}
\hline \multicolumn{2}{|c|}{ Model } & Sum of Squares & df & Mean Square & $\mathbf{F}$ & Sig. \\
\hline \multirow{3}{*}{1} & Regression & 2.065 & 4 & .516 & 1.353 & $.300^{\mathrm{b}}$ \\
\hline & Residual & 5.343 & 14 & .382 & & \\
\hline & Total & 7.408 & 18 & & & \\
\hline
\end{tabular}

\begin{tabular}{c|c}
\hline Predictors & Standardized Coefficients (Beta) \\
\hline IVA & 2.149 \\
\hline TXC & -4.539 \\
\hline RTR & 1.921 \\
\hline TXH & .335 \\
\hline \multicolumn{2}{c}{ Source: Researchers Computation using SPSS v 20.}
\end{tabular}

The results show that both cost based tax incentives and profit based incentives correlate with FDI. More so, the Durbin Watson value of 1.518 suggests that there are no significant autocorrelation problems. The $\mathrm{R}$ square value of 0.279 depicts that taken jointly, these tax incentives (both cost and profit based) explain only $27.9 \%$ of the variance in FDI which is quite insignificant. In other words, $72.9 \%$ of the variance in FDI is accounted for by non-tax incentive variables. This insignificance is further highlighted by $\mathrm{p}$ value of .300 which is greater than .05. The implication of these is that, in contrast to the findings of Effiok et al. (2013); Amuka and Ezeudeka (2017); Ugwu (2018); Olaniyi et al. (2018), the greater part of variance in FDI is accounted for by non-tax incentive variables. This stance is in line with the findings of Peters and Kiabel (2015).

Moreover, of the two categories of tax incentives, the standardized beta coefficient highlight that cost based incentives (TXC and IVA with coefficients of -4.539 and 2.149 respectively) make a relatively stronger effect on FDI than profit based incentives (RTR and TXH with coefficients of 1.921 and .335 respectively). Where these incentives are jointly implemented, these standardized beta coefficients imply that a $1 \%$ increase in tax credits will affect FDI by $4.539 \%$. Also a $1 \%$ increase in IVA will increase FDI by $2.149 \%$. On the other hand, for the profit based incentives, a $1 \%$ reduction in tax rate (RTR) increase FDI by $1.921 \%$ while FDI will 
increase by only $0.335 \%$ for each year of tax holiday granted. These findings are not too different from that of Klemm and Parys (2009).

On the basis of this results, the null hypothesis is confirmed that there is no significant joint relationship between cost based tax incentives, profit based incentives and FDI.

\section{Conclusion and Recommendations}

This study was undertaken with a view to confirming the contrasting findings of previous studies on the effect of tax incentives on FDI in Nigeria. Based on the earlier discussed findings of the study, after evaluating the two broad categories of incentives (cost based and profit based incentives), it is concluded that cost based incentives (investment allowances and tax credits) exert a relatively stronger effect on FDI compared to the profit based tax policy incentives (reduced tax rates and tax holidays). On the whole, it is concluded that contrary to the opinions of several previous studies, tax policy incentives (both cost based and profit base), have no significant relationship with FDI in Nigeria.

It is therefore recommended that government and foreign investment policy makers should enhance the efficiency and effectiveness in the implementation of investment allowances, tax credits and other cost based tax policy incentives for foreign investors. Profit based incentives may also need to be reviewed in order to yield more results. More importantly, there is a glaring need to identify and prioritize focus on possible nontax incentive measures that will complement tax incentives for the attraction and stabilization of FDI in Nigeria.

\section{References}

Akhor, S. O., \& Ekundayo, O. U. (2016). The impact of indirect tax revenue on economic growth: The Nigeria experience. Igbinedion University Journal of Accounting, 2, 62-87.

Amuka, J., \& Ezeudeka, F. (2017). Tax incentives and the flow of foreign direct investment to non-oil sector: Empirical. Asian Journal of Social Sciences and Management Studies, 4(1), 57-64.

Berkeley. (2019). Foreign direct investment and applicable tax incentives. Retrieved from www.berkeleylegal.com.ng/2018/03/16/foreign-direct-investment-and-applicable-tax-incentives/. [Accessed 9th April, 2019].

Chen, J. (2018). Investment. Retrieved from https://www.investopedia.com/terms/i/investment.asp. [Accessed, 9th April, 2019].

Easson, A., \& Zolt, E. (2002). Tax Incentives. Retrieved from http://siteresources.worldbank.org/INTTPA/ Resources/EassonZoltPaper.pdf.

Effiok, S. O., Tapang, A. T., \& Eton, O. E. (2013). The impact of tax policy and incentives on foreign direct investment (FDI) and economic growth: Evident from Export Processing Zones (EPZs) in Nigeria. European Journal of Commerce and Management Research, 2(9), 192-196.

Essays, U. K. (2018). Theories of foreign direct investment (FDI). Retrieved from https://www.ukessays.com/essays/ economics/various-theories-concerning-foreign. [Accessed 24th March, 2019].

Hymer, S. H. (1976). The international operations of national firms: A study of foreign direct investment. PhD Dissertation, Cambridge, MA: MIT Press.

Institute for Fiscal Studies (IFS). (2018). Review of corporate tax incentives for investment in low-and middle-income countries (pp. 1-48). London: The Institute for Fiscal Studies.

Jhingan, M. L. (2004). Money, banking, international trade and public finance. Delhi: Vrinda Publications Ltd.

Kenton, W. (2018). Accelerated depreciation. investopedia. Retrieved from https://www.investopedia.com/terms/a/ accelerateddepreciation.asp. [Accessed, 24th March, 2019].

Klemm, A. (2010). Causes, benefits, and risks of business tax incentives. International Tax and Public Finance, 17, 315-336.

Klemm, A., \& Parys, S. V. (2009). Empirical evidence on the effects of tax incentives. IMF Working Paper WP/o9/13 (pp. $1-25)$.

Ndagi, M. (2016). An appraisal of taxation and its legal effects on foreign direct investment in Nigeria. A Ph.D Thesis Submitted to School of Post Graduate Studies, Ahmadu Bello University, Zaria.

Ndajiwo, M. (2018). Are tax incentives in Nigeria attracting investment or giving away revenue? Retrieved from https://www.taxjustice.net/2018/08. [Accessed, 7th March, 2019].

Odiase, O. A. (2006). An appraisal of the legal and institutional regime for foreign investment promotion and protection in Nigeria. FIPGW Journal, NIALS, Lagos.

Okauru, I. O. (2009). Tax incentives for foreign investors in Nigeria. Paper presented at the A Paper Presented at the Nigeria Investors Business Forum, Berne Switzerland.

Olaniyi, T. A., Ajayi, R. O., \& Oyedokun, G. E. (2018). Tax policy incentives and foreign direct investment in Nigeria. Fountain University Osogbo Journal of Management, 3(3), 59-71.

Peters, G. T., \& Kiabel, B. D. (2015). Tax incentives and foreign direct investment in Nigeria. IOSR Journal of Economics and Finance, 6(5), 10-20.

PwC. (2018). Nigeria corporate tax credits and incentives. Retrieved from www.taxsummaries.pwc.com/ID/NigeriaCorporate-Tax-credits-and-incentives. [Accessed 31 st March, 2019].

Rugman, A. M., \& Collinson, S. (2012). International business: Pearson.

Saidu, A. S. (2015). Corporate taxation and foreign direct investment in Nigeria. European Journal of Accounting, Auditing and Finance Research, 3(8), 17-24.

Sheedy, E., Zhang, L., \& Tam, C. H. (2017). Are profit based incentives compatible with a risk culture? Experimental Research Report, 1-11. 
Smith, G., Pepelasis, A. A., Paya, M. L., \& McLure, C. E. (2019). Tariff reduction and the growth of international trade. Encyclopaedia Britannica. Retrieved from https://www.britannica.com/topic/tariff.

Tapang, A. T., Onodi, B. E., \& Amaraihu, A. H. (2018). Effect of Tax incentives on foreign direct investment in Nigeria. IIARD International Journal of Economics and Business Management, 4(7), 30-39.

Trading Economics. (2019). Nigeria foreign direct investment. Retrieved from http://tradingeconomics.com/nigeria/foreign-direct-investment. [Accessed, 15th March, 2019].

Trivedi, S. R. (2009). Evolution of the concept of capital - A historical perspective. Munich Personal RePEc Archive, Paper No. 14208. Retrieved from https://mpra.ub.uni-muenchen.de/14208/.

Ugwu, J. I. (2018). Tax incentives and foreign direct investment (FDI): Implication for export promotion in Nigeria, Ghana and South Africa, Post IFRS adoption. International Journal in Management and Social Science, 6(9), 31-52.

United Nations Conference on Trade and Development (UNCTAD). (2018). World investment report: Investment and New Industrial Policies (pp. 213).

World Bank. (2019). Foreign direct investment net inflows (\% of GDP). Retrieved from https://data.worldbank.org/indicator/bx.kit.dinv.wd.gd.zs. [Accessed, 26th March, 2019]. 